\title{
Acacetin Blocks Kv1.3 Channels and Inhibits Human T Cell Activation
}

\author{
Ning Zhao ${ }^{a}$ Qian Dong ${ }^{a}$ Xiao-Xing Fu ${ }^{a} \quad$ Li-Li Dua Xiang Cheng ${ }^{a} \quad$ Yi-Mei Du ${ }^{a}$ \\ Yu-Hua Liao ${ }^{a}$ \\ aResearch Center of Ion Channelopathy, Institute of Cardiology, Union Hospital, Tongji Medical College, \\ Huazhong University of Science and Technology, Wuhan, P.R. China
}

\section{Key Words}

Acacetin $\cdot$ Kv1.3 potassium channel Chemical blockade Immunomodulatory - Human T cells

\begin{abstract}
Backgrounds/Aims: Acacetin, a natural flavonoid compound, has been proven to exert antiinflammatory and immunomodulatory effects. Kv1.3 channels, highly expressed in human T cells, are attractive therapeutic targets to treat inflammatory and immunological disorders. The present study was designed to characterize the inhibition of Kv1.3 channels by Acacetin in human T cells and examine its role in T cell activation. Methods: Whole-cell patch-clamp was applied to record the Kv1.3 and $\mathrm{K}_{\mathrm{Ca}}$ currents in human T cells; Western blot was used to detect Kv1.3 expression as well as NFAT1 and NF-KB activity; Fluo-4, CCK-8 and an ELISA kit were used to measure $\mathrm{Ca}^{2+}$ influx, proliferation, and IL-2 secretion, respectively. Results: Acacetin decreased the Kv1.3 current, accelerated the decay rate and negatively shifted the steadystate inactivation curves in a concentration-dependent manner. The $\mathrm{IC}_{50}$ values at $+40 \mathrm{mV}$ for peak and the current at end of pulse were $21.09 \pm 2.75$ and $3.63 \pm 0.25 \mu \mathrm{mol} / \mathrm{L}$, respectively. Treatment with Acacetin for $24 \mathrm{~h}$ significantly inhibited Kv1.3 protein expression. Additionally, paralleling Kv1.3 inhibition, Acacetin also inhibited $\mathrm{Ca}^{2+}$ influx, the $\mathrm{Ca}^{2+}$-activated transcription factors NFAT1, NF-KB p65/p50 activity, and proliferation as well as IL-2 production. Small interfering RNA against Kv1.3 reduced the inhibitory effect of Acacetin on IL-2 secretion. Conclusions: Acacetin blocks the Kv1.3 channel and inhibits human T cell activation. This action most likely contributes to its immunomodulatory and anti-inflammatory actions.
\end{abstract}

Copyright (C) 2014 S. Karger AG, Basel

\section{Introduction}

Acacetin (5, 7-dihydroxy-4'-methoxyflavone), a natural flavonoid compound, has been reported to have anti-peroxidative, anti-proliferative and anti-inflammatory activities $[1,2]$. Importantly, it has been demonstrated that Acacetin significantly inhibits the concanavalin 
A-induced proliferation of $\mathrm{T}$ cells and was effective at ameliorating $\mathrm{T}$ cell-mediated autoimmune delayed-type hypersensitivity without toxicity [3], which suggests that it might be effective for the treatment of T cell-mediated inflammatory diseases. However, the mechanisms underlying the action of Acacetin require further study.

Acacetin has been found to block multiple potassium channels, including cloned Kv1.3 channels expressed in recombinant cell lines $[4,5]$. The Kv1.3 channel, a member of the Shaker family of potassium channels, is mainly expressed in immune cells such as T cells, macrophages and dendritic cells [6-8]. In human T cells, the Kv1.3 channel along with the $\mathrm{K}_{\mathrm{Ca}} 3.1\left(\mathrm{Ca}^{2+}\right.$ activated-potassium) channel grants $\mathrm{K}^{+}$efflux, thus maintaining negative membrane potential for further $\mathrm{Ca}^{2+}$ entry through the $\mathrm{CRAC}\left(\mathrm{Ca}^{2+}\right.$ release activated calcium) channel. This $\mathrm{Ca}^{2+}$ influx activates the related transcription factors NFAT and NF$\kappa B$, causing both T cell proliferation and IL-2 secretion [6,9]. Many studies, including ours, have verified that the blockade of Kv1.3 channels resulted in the reduction of $\mathrm{Ca}^{2+}$ influx and functional inhibition of T cell activation [10-14], thus producing anti-inflammatory and immunomodulation effects [15-18]. Therefore, the Kv1.3 channel has become an attractive therapeutic target for inflammatory and immunological disorders [19].

In the present study, we first evaluated the action of Acacetin on the Kv1.3 channels and further investigated the effects of Acacetin on $\mathrm{Ca}^{2+}$ influx and the $\mathrm{Ca}^{2+}$-activated transcription factors NFAT1 and NF- $\kappa B$ p65/p50. Finally, we examined the effect of Acacetin on T cell proliferation and IL-2 secretion in the absence and presence of Kv1.3-siRNA. We demonstrate for the first time that Acacetin blocks Kv1.3 channels, attenuates $\mathrm{Ca}^{2+}$ influx, down-regulates the activity of the $\mathrm{Ca}^{2+}$-activated transcription factors NFAT1 and NF- $\kappa$ B p65/p50 and inhibits $\mathrm{T}$ cell activation.

\section{Materials and Methods}

\section{Ethics statement}

In this study, the study protocol with healthy volunteers' blood samples was conducted in accordance with the Declaration of Helsinki and Tokyo for humans and approved by the Ethics Committee of Tongji Medical College, Huazhong University of Science and Technology. Healthy blood donors provided written informed consent for the collection of blood and subsequent $\mathrm{T}$ cell isolation and analysis.

\section{Chemicals}

Acacetin, Phytohematogglutinin (PHA), phorbol ester (PMA) and others not specially mentioned were obtained from Sigma-Aldrich (St Louis, MO, USA). Fluo-4 AM was purchased from Invitrogen (Carlsbad, CA, USA), and thapsigargin (TG) was obtained from Alomone Laboratories (Jerusalem, Israel). RPMI 1640 medium, fetal bovine serum, and penicillin/streptomycin were purchased from Gibco (Grand Island, NY, USA). Acacetin was dissolved in DMSO at $100 \mathrm{mmol} / \mathrm{L}$ stock concentration. All aliquoted stock was kept light protected at $-20^{\circ} \mathrm{C}$. For all experiments, final concentrations of DMSO in culture medium were no more than $0.1 \%$, and the control with DMSO was used to discard the possible non-specific effects.

\section{Cell culture}

The human T cell-line Jurkat (E6-1) was obtained from the China Center for Type Culture Collection (Wuhan, China). Human peripheral blood mononuclear cells were separated using density Ficoll gradients from the whole blood of healthy volunteers. Next, CD4 ${ }^{+} \mathrm{T}$ cells were purified using a $\mathrm{CD} 4^{+} \mathrm{T}$ Cell Isolation Kit (Miltenyi Biotec, Bergisch-Gladbach, Germany). All cells mentioned above were maintained in RPMI 1640 medium supplemented with 10\% heat-inactivated fetal bovine serum, $10 \mathrm{mmol} / \mathrm{L} \mathrm{HEPES,} 2 \mathrm{mmol} / \mathrm{L}$ L-glutamate and $1 \%$ penicillin/streptomycin at $37^{\circ} \mathrm{C}$ in humidified atmosphere $\left(5 \% \mathrm{CO}_{2}\right.$ and $95 \%$ air $)$.

\section{Electrophysiological recordings and analysis}

Electrophysiology recordings were performed in the whole-cell recording mode of the patch-clamp technique at room temperature as described in our previous study [14]. Transmembrane ionic currents were recorded under the voltage clamp. The resting membrane potential (RMP) was measured in zero current $(\mathrm{I}=0)$ mode $[20,21]$. The external Ringer solution was as follows (in mmol/L): $\mathrm{NaCl}, 137 ; \mathrm{KCl}, 4 ; \mathrm{CaCl}_{2}$, 
1.8; $\mathrm{MgCl}_{2}, 1$; glucose, 10; and HEPES, 10. For RMP and Kv1.3 recording, the internal solution contained (in mmol/L): KCl, 130; $\mathrm{MgCl}_{2}$, 1; EGTA, 5; Mg-ATP, 5; HEPES, 10, adjusted to $\mathrm{pH} 7.2$ with KOH. For $\mathrm{K}_{\mathrm{Ca}}$ recording, the internal solution consisted of the following (in mmol/L): potassium aspartate, 130; EGTA, 10; $\mathrm{CaCl}_{2}$, 8.55; $\mathrm{MgCl}_{2}, 2.08$; and HEPES, 10, adjusted to $\mathrm{pH} 7.2$ with $\mathrm{KOH}$. For some experiments recording $\mathrm{K}_{\mathrm{Ca}^{\prime}}$ the external solution was replaced with a $\mathrm{K}^{+}$Ringer solution, which featured identical ingredients, except that all $\mathrm{NaCl}$ was substituted with $\mathrm{KCl}$. Voltage pulse protocols are described in the Results and in the Figure Legends. The time constant for the Kv1.3 current decay, $\%$ inhibition, IC $_{50}$ (concentration required for $50 \%$ inhibition of the channel currents), Hill coefficient, membrane conductance $(G)$, half-maximum voltage of activation or inactivation $\left(V_{1 / 2}\right)$ and the slope factors $(\kappa)$ were all acquired using the same equations as previously described [14]. The decay phase of the Kv1.3 current at $+40 \mathrm{mV}$ was fitted to a mono-exponential equation. The inhibition \% was defined as $\left(\mathrm{I}_{\text {control }} \mathrm{I}_{\text {drug }}\right) / \mathrm{I}_{\text {control }}{ }^{*} 100 \%$. G was defined as $I /\left(V-\mathrm{E}_{\text {rev }}\right)$, where $I$ is the peak amplitude, $V$ is the test voltage, and $\mathrm{E}_{\text {rev }}$ is the reversal potential $(-90 \mathrm{mV})$ of the Kv1.3 currents. The steady-state inactivation curve was studied using a double-pulse protocol, in which the test voltage was stepped to $+40 \mathrm{mV}, 200 \mathrm{~ms}$ long, and preceded by $30 \mathrm{~s}$ preconditioning pulses from -80 to $0 \mathrm{mV}$ in 10 $\mathrm{mV}$ steps. The data for activation and steady-state inactivation were fitted with the Boltzmann equation to obtain $V_{1 / 2}$ and the slope factor. The concentration-dependent shift in the inactivation $V_{1 / 2}(\Delta V)$ was determined as the difference between $V_{1 / 2}$ values in the control and with various concentrations of Acacetin application. $\operatorname{Exp}(\Delta V / \kappa)$ was then plotted with the Acacetin concentrations and linear fit was used to obtain the reciprocal of the slope, $K_{i}$ The pCLAMP 9.0 software (Molecular Devices, Union City, CA, USA) was used for data acquisition and Origin 8.5 (OriginLab Corporation, Northampton, MA, USA) for the data analysis. No leak subtraction protocol was applied.

\section{Cell viability assay}

Jurkat cells were seeded into a 24-well plate and treated with Acacetin at various time points. Cell viability was assessed using the Cell Counting Kit-8 (CCK-8, Dojindo Molecular Technologies, Tokyo, Japan). CCK-8 solution $(20 \mu \mathrm{L})$ was added to every well for the last $2 \mathrm{~h}$, and the optical density (OD) value of each well at $450 \mathrm{~nm}$ wavelength was recorded. The cell viability is calculated as the percentage of $\left(\mathrm{OD}_{\text {test }}-\right.$ $\left.\mathrm{OD}_{\text {blank }}\right) /\left(\mathrm{OD}_{\text {control }}-\mathrm{OD}_{\text {blank }}\right)$, where $\mathrm{OD}_{\text {test }}$ is the $\mathrm{OD}$ value of the cells exposed to Acacetin, $\mathrm{OD}_{\text {control }}$ is the $\mathrm{OD}$ of the control sample and $\mathrm{OD}_{\text {blank }}$ is the $\mathrm{OD}$ of the wells without Jurkat cells. Alternatively, cell viability was determined using a Trypan blue dye exclusion assay as described previously [11]. Values were calculated relative to DMSO-treated cells.

\section{RNA isolation and quantitative real-time PCR}

Jurkat cells were seeded and treated with various concentrations (10, 30, $100 \mu \mathrm{mol} / \mathrm{L})$ of Acacetin for $24 \mathrm{~h}$. The protocols for total RNA extraction and cDNA synthesis were performed as described in our previous paper [11]. The primers used are as follows: Kv1.3 forward primer: 5'-TTCTCCTTCGAACTGCTGGT-3', reverse primer: 5'-TGAAGATGCGGAAGACCCTT-3'; GAPDH forward primer: 5'-CATGAGAAGTATGACAACAGCCT-3', reverse primer: 5'-AGTCCTTCCACGATACCAAAGT-3'. In all experiments, negative controls were applied in the absence of the reverse transcriptase reaction and GAPDH were used as controls. The relative expression quantity $2^{-\Delta \Delta C t}$ value was calculated to compare the differences among the groups.

\section{Western Blot}

For the measurement of Kv1.3 channel protein expression levels, Jurkat cells were treated with 10, 30 or $100 \mu \mathrm{mol} / \mathrm{L}$ Acacetin for $24 \mathrm{~h}$. To measure NFAT1 and NF- $\mathrm{kB}$ activity, Jurkat cells were stimulated with PHA $(5 \mu \mathrm{g} / \mathrm{mL})$ and PMA $(80 \mathrm{nmol} / \mathrm{L})$ for $4 \mathrm{~h}$ with or without the 30 min pretreatment of 10,30 or $100 \mu \mathrm{mol} / \mathrm{L}$ Acacetin. Next, the Jurkat cell lysate was prepared and analyzed as described previously [14]. Primary antibodies against Kv1.3 (Alomone Labs), NFAT1 (Genetex, Irvine, CA, USA), phospho-NF- $\mathrm{kB}$ p65/ p50 (Cell Signaling Technology, Beverly, MA, USA), and GAPDH (Santa Cruz Biotechnology Inc, CA, USA) were applied. The protein expression levels were detected and analyzed by enhanced chemiluminescence using Image Lab Software (Bio-Rad, Richmond, CA, USA). GAPDH expression was used as an internal reference.

\section{Intracellular calcium measurement}

Intracellular calcium was measured as described previously [11]. Briefly, Jurkat cells were loaded with Fluo-4 AM and seeded into 96-well plate $\left(2 \times 10^{5} /\right.$ well) with $0,10,30,100 \mu \mathrm{mol} / \mathrm{L}$ Acacetin for 30 
min incubation. TG $(1 \mu \mathrm{mol} / \mathrm{L})$ was used to induce the $\mathrm{Ca}^{2+}$ release in $\mathrm{Ca}^{2+}$ free Ringer's solution, then $\mathrm{CaCl}_{2}$ $\left(2 \mathrm{mmol} / \mathrm{L}\right.$ ) was applied for the subsequent $\mathrm{Ca}^{2+}$ influx. The composition of the $\mathrm{Ca}^{2+}$-free Ringer solution was as follows (in mmol/L): $\mathrm{NaCl}, 155 ; \mathrm{KCl}, 4.5 ; \mathrm{MgCl}_{2}$, 3; Glucose, 10; HEPES, 5; EGTA, 1 [22]. The $\mathrm{Ca}^{2+}$ concentration was calculated with the formula $\left[\mathrm{Ca}^{2+}\right]=\mathrm{K}_{\mathrm{d}}^{*}\left(F-F_{\min }\right) /\left(F_{\max }{ }^{-F}\right)$, as described in our previous study [11].

Determination of cell proliferation

Cell proliferation was measured using CCK-8 as described above. CD4 ${ }^{+} \mathrm{T}$ cells were seeded in 96well round-bottom plates at $5 \times 10^{5}$ cells per well in $200 \mu \mathrm{L}$ complete medium. Every group contained 3-4 duplicates. T cells were pre-treated with $3,10,30$, or $100 \mu \mathrm{mol} / \mathrm{L}$ Acacetin for $30 \mathrm{~min}$, then $1 \mu \mathrm{g} / \mathrm{mL}$ soluble purified anti-CD3 and anti-CD28 antibodies (eBioscience, San Diego, CA, USA) were added to stimulate the $\mathrm{CD} 4^{+} \mathrm{T}$ cells for 3 days.

\section{IL-2 measurement by ELISA}

IL-2 production from Jurkat cells was measured using an ELISA kit (eBioscience) following the manufacturer's instructions. Cells were stimulated using PHA (5 $\mu \mathrm{g} / \mathrm{mL})$ and PMA (80 nmol/L) for $24 \mathrm{~h}$. Acacetin in various concentrations was added $30 \mathrm{~min}$ prior to stimulation. The supernatants were collected for subsequent assays. Each experiment was repeated at least three times in duplicate.

Knockdown of Kv1.3 expression with small interfering RNA

Human Jurkat cell lines stably transfected with lentivirus-delivered negative control (NC)-siRNA or Kv1.3-siRNA were provided by the Genepharma Company (Shanghai, China). A Western blot was performed to confirm the efficiency of siRNA knockdown. The cells were pre-incubated with $100 \mu \mathrm{mol} / \mathrm{L}$ Acacetin for 30 min, then stimulated with PHA + PMA for $24 \mathrm{~h}$. The supernatants were collected for IL-2 measurement.

\section{Statistical Analysis}

All results are presented as the mean \pm SEM. The significance of differences before and after drug treatment was evaluated using paired t-test. Comparisons between groups were carried out by analysis of variance with Turkey's post-test. Significance was set at $\mathrm{P}<0.05$.

\section{Results}

Acacetin blocks Kv1.3 channel currents in Human T cells

We examined the effects of Acacetin on Kv1.3 currents in Jurkat cells, a human T cellline, using $300 \mathrm{~ms}$ pulses at test potentials from -80 to $+60 \mathrm{mV}$ in $10 \mathrm{mV}$ steps from a holding potential of $-80 \mathrm{mV}$. In the control condition, the Kv1.3 currents were characterized by rapid activation and slow inactivation at potentials positive to $-30 \mathrm{mV}$ (Fig. $1 \mathrm{~A}$ ), as we previously reported [14]. However, the currents became smaller and appeared to inactivate faster (Fig. $1 B$ ) after the application of $10 \mu \mathrm{mol} / \mathrm{L}$ Acacetin, and the effect partially recovered upon washout (Fig. 1C). Similar results were obtained in peripheral blood T cells (PBTC) (Fig.1 $D-F)$. We then investigated the time course block in PBTC using a voltage step to $+40 \mathrm{mV}$ from a holding potential of $-80 \mathrm{mV}(0.1 \mathrm{~Hz})$. As shown in Fig. $1 G$, the steady-state block was reached within $15 \mathrm{~min}$. The current amplitude was measured both at the peak (open circle, peak current) and at the end of a pulse to $+40 \mathrm{mV}$ (filled circle, current at the end of the pulse). The inhibitory effect gradually recovered upon washout. Peak currents were nearly reversible, but currents at the end of the pulse recovered only partially. Fig. $1 H$ shows the corresponding representative current traces.

Concentration-dependent block of Kv1.3 channel currents by Acacetin in Jurkat cells

The effects of Acacetin on Kv1.3 channels over a wide range of concentrations, from 0.3 to $100 \mu \mathrm{mol} / \mathrm{L}$, confirmed that this blocking effect was concentration-dependent. Kv1.3 currents were elicited with repetitive $250 \mathrm{~ms}$ depolarizing pulses at $+40 \mathrm{mV}$ from a holding potential of $-80 \mathrm{mV}$ every $10 \mathrm{~s}$. Fig. $2 \mathrm{~A}$ shows the representative superimposed current traces recorded in a single Jurkat cell in the absence and presence of 3,10 , or $100 \mu \mathrm{mol} / \mathrm{L}$ Acacetin. 


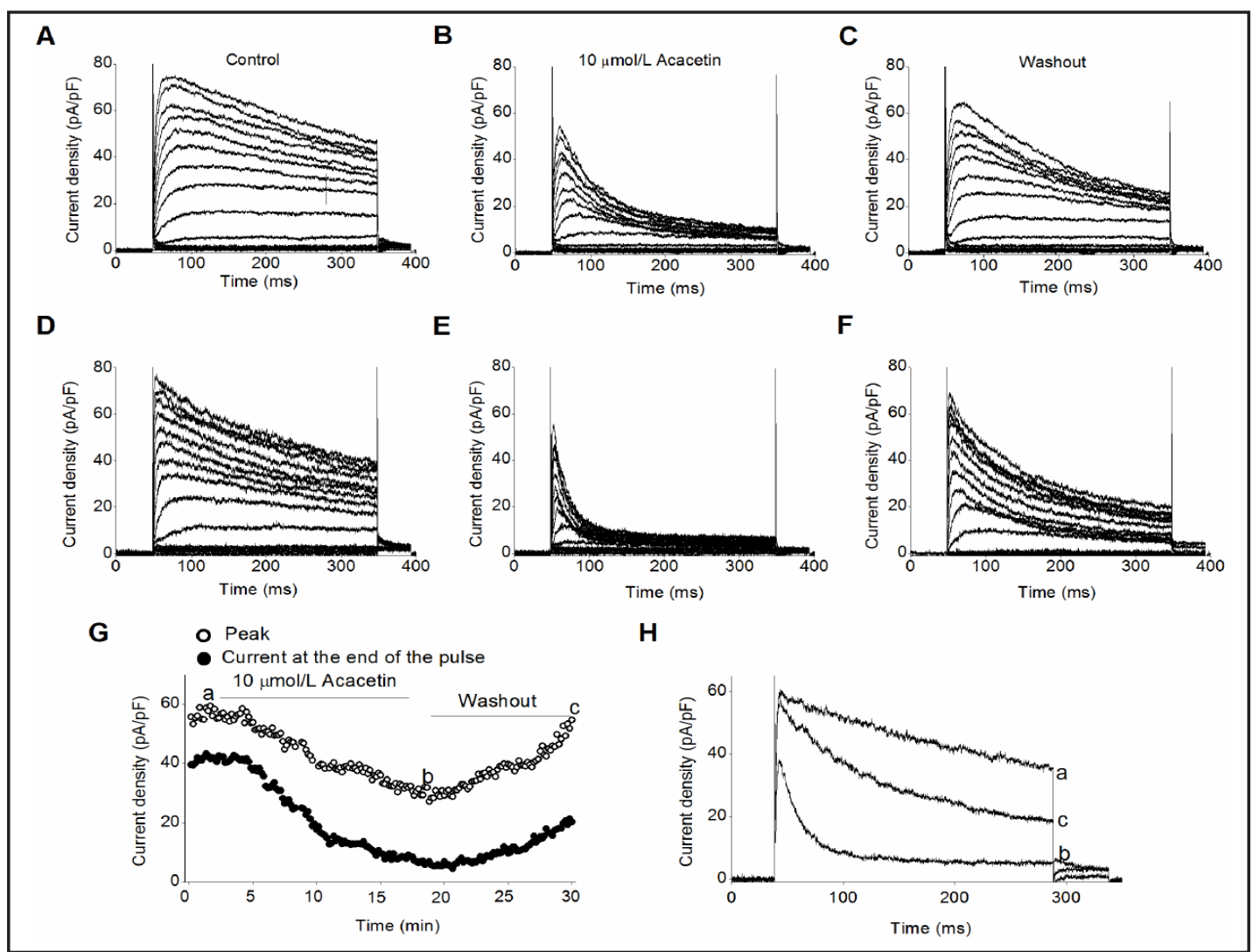

Fig. 1. Inhibition of Kv1.3 channel currents by Acacetin in human T cells. A-C. Representative voltage-dependent Kv1.3 traces recorded in a Jurkat cell in the absence $(A)$, presence $(B)$ and washout $(C)$ of $10 \mu \mathrm{mol} / \mathrm{L}$ Acacetin. Kv1.3 currents were elicited using $300 \mathrm{~ms}$ pulses at test potentials from -80 to $+60 \mathrm{mV}$ in $10 \mathrm{mV}$ steps, from a holding potential of $-80 \mathrm{mV}$ every $10 \mathrm{~s}$. The $10 \mathrm{~s}$ pulse interval might not be long enough to avoid the accumulated inactivation, although the stable currents were obtained in our recording condition (data not shown). D-F. Representative Kv1.3 currents recorded in a PBTC in the absence $(D)$, presence $(E)$ and washout $(F)$ of $10 \mu \mathrm{mol} / \mathrm{L}$ Acacetin using the same protocol as in A-C. G. Time course of peak (open circle) and the current at the end of the pulse (filled circle) during Kv1.3 current inhibition by $10 \mu \mathrm{mol} / \mathrm{L}$ Acacetin in a single PBTC. Currents were elicited by depolarizing step pulses at the test potential of $+40 \mathrm{mV}$ from the holding potential of $-80 \mathrm{mV}$ every $10 \mathrm{~s}$. H. The original current traces at the indicated time points a, b, c in Fig. $1 G$.

The dose-dependent inhibition of the peak current and the current at the end of the pulse were analyzed quantitatively (Fig. $2 B$ ). A nonlinear least-squares fit of dose response plots with the Hill equation yielded an $\mathrm{IC}_{50}$ and Hill coefficient of $21.09 \pm 2.75 \mu \mathrm{mol} / \mathrm{L}$ and $0.55 \pm$ $0.03(n=6)$, respectively, for the peak current and $3.63 \pm 0.25 \mu \mathrm{mol} / \mathrm{L}$ and $0.77 \pm 0.03(\mathrm{n}=6)$, respectively, for the current at the end of the pulse. The effects of Acacetin on the Kv1.3 channel decay rate were also analyzed. The decay phase of the Kv1.3 current at $+40 \mathrm{mV}$ was well fitted to a mono-exponential equation, yielding a time constant of $212.7 \pm 21.3 \mathrm{~ms}$ in the control, and $161.3 \pm 19.3(\mathrm{P}>0.05), 99.0 \pm 7.5(\mathrm{P}<0.01), 52.9 \pm 6.7(\mathrm{p}<0.001), 16.0 \pm$ $3.7(\mathrm{p}<0.001) \mathrm{ms}$ in the presence of $3,10,30,100 \mu \mathrm{mol} / \mathrm{L}$ Acacetin, respectively (Fig. 2C). Therefore, like many other Kv1.3 open channel blockers [14, 23, 24], Acacetin accelerated the channel decay rate in a concentration-dependent manner.

\section{Blocking kinetics of Acacetin on Kv1.3 channels}

We further evaluated the biophysical effects of Acacetin on Kv1.3 channels in Jurkat cells. The current density-voltage relationships for the peak currents and the currents at the end of the pulse, as in Fig. $3 A$ and $3 B$, indicated that Acacetin reduced both current amplitudes 


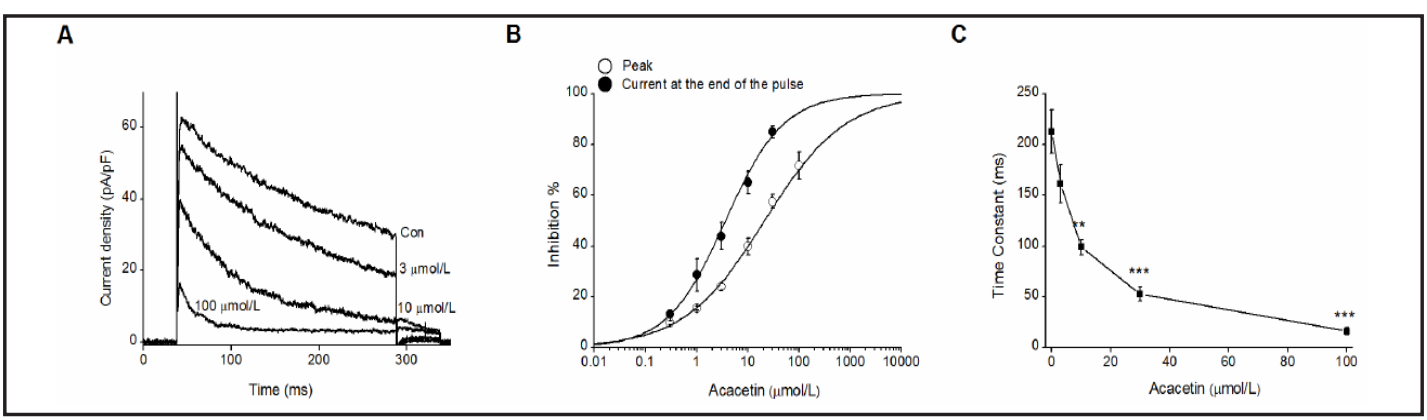

Fig. 2. Concentration-dependent block of Kv1.3 channels by Acacetin in Jurkat cells. A. Superimposed representative current traces recorded in the absence and presence of 3, $10 \mathrm{or} 100 \mu \mathrm{mol} / \mathrm{L}$ Acacetin in one Jurkat cell. Kv1.3 currents were elicited with repetitive $250 \mathrm{~ms}$ depolarizing pulses at $+40 \mathrm{mV}$ from the holding potential of $-80 \mathrm{mV}$ every $10 \mathrm{~s}$. B. The dose-response curves of the peak (open circle) and the current at the end of the pulse (filled circle) for Kv1.3 currents fitted with the Hill equation. The summarized data from 6 cells are expressed as the mean \pm SEM for each concentration. The IC $_{50}$ and Hill coefficient were $21.09 \pm$ $2.75 \mu \mathrm{mol} / \mathrm{L}$ and $0.55 \pm 0.03$, respectively, for the peak current, and were $3.63 \pm 0.25 \mu \mathrm{mol} / \mathrm{L}$ and $0.77 \pm 0.03$ $(n=6)$, respectively, for the current at the end of the pulse. C. Time constant for the Kv1.3 current decay at $+40 \mathrm{mV}$ was measured using a mono-exponential equation and plotted against the Acacetin concentration (** $\mathrm{P}<0.01,{ }^{* * *} \mathrm{P}<0.001$ vs. control).

for the entire voltage range over which this current was activated. To examine the voltagedependence of this blockade, the percent inhibition by $30 \mu \mathrm{mol} / \mathrm{L}$ Acacetin at the end of the pulse was plotted as a function of the test potential together with the activation curve (Fig. $3 C$ ). In the presence of Acacetin, the inhibition percentage increased steeply between -40 and $0 \mathrm{mV}$, from $34.1 \%$ to $56.8 \%$, corresponding to the voltage range for channel opening. This inhibition reached a plateau value between +10 and $+60 \mathrm{mV}$ when the Kv1.3 channels were fully activated (Fig. $3 C$ ). These data suggest that Acacetin may bind to the open form of the Kv1.3 channels.

To further determine whether blocking the Kv1.3 channels with Acacetin requires channel opening, we recorded the currents in Jurkat cells before and after a pulse-free period of incubation with the compound. During the pulse pause, the membrane potential was kept at $-80 \mathrm{mV}$ to ensure all channels were in the close state. After resuming the voltage steps, Acacetin did not affect the peak current at pulse 1 (81.13 vs $81.27 \mathrm{pA} / \mathrm{pF}$ under control conditions) but significantly accelerated the decay of the Kv1.3 channel current (the time constants of the decay were $268.54 \mathrm{~ms}$ under control and $148.74 \mathrm{~ms}$ at pulse 1 ). These results indicate that Acacetin preferentially binds to the open state of the Kv1.3 channel rather than the close state.

To investigate the effects of Acacetin on the voltage dependence of channel availability, steady-state inactivation curves were generated using standard double-pulse protocols [14]. The resulting curves were fitted with the Boltzman equation to obtain $V_{1 / 2}$ and $\kappa$ in Fig. $3 E$. In control conditions, the $V_{1 / 2}$ value was $-40.91 \pm 0.96$ and $\kappa$ was $3.98 \pm 0.42 \mathrm{mV}$. Acacetin caused a negative shift of the steady-state inactivation curves in a concentration-dependent fashion $(-46.32 \pm 0.99$ at $10,-51.94 \pm 1.08$ at $30 \mu \mathrm{mol} / \mathrm{L}$ Acacetin; $\mathrm{P}<0.05$ and $\mathrm{P}<0.001$, respectively), which suggests that Acacetin may block the inactivated-state channel. However, Acacetin did not change the $\kappa$ value $(4.53 \pm 0.33$ at $10,5.28 \pm 0.36$ at $30 \mu \mathrm{mol} / \mathrm{L} ; \mathrm{P}>0.05)$. The $K_{i}$ value for the possible Acacetin-induced inhibitory effect in the inactivated state was calculated as 3.85 $\pm 1.17 \mu \mathrm{mol} / \mathrm{L}$ (Fig. $3 \mathrm{~F}$ ). Thus, the effect of Acacetin on channel inactivation was 5 times more potent than on the peak current $(21.09 \pm 2.75 \mu \mathrm{mol} / \mathrm{L})$, whereas it was equally potent on the current at the end of the pulse $(3.63 \pm 0.25 \mu \mathrm{mol} / \mathrm{L})$.

\section{Acacetin does not block KCa channel currents in human T cells}

We further examined the effects of Acacetin on $\mathrm{K}_{\mathrm{Ca}}$ channel in human $\mathrm{T}$ cells. The main $\mathrm{K}_{\mathrm{Ca}}$ channel involved in the $\mathrm{Ca}^{2+}$ signaling of Jurkat cells is $\mathrm{K}_{\mathrm{Ca}} 2.2$, whereas $\mathrm{K}_{\mathrm{Ca}} 3.1$ is the main 


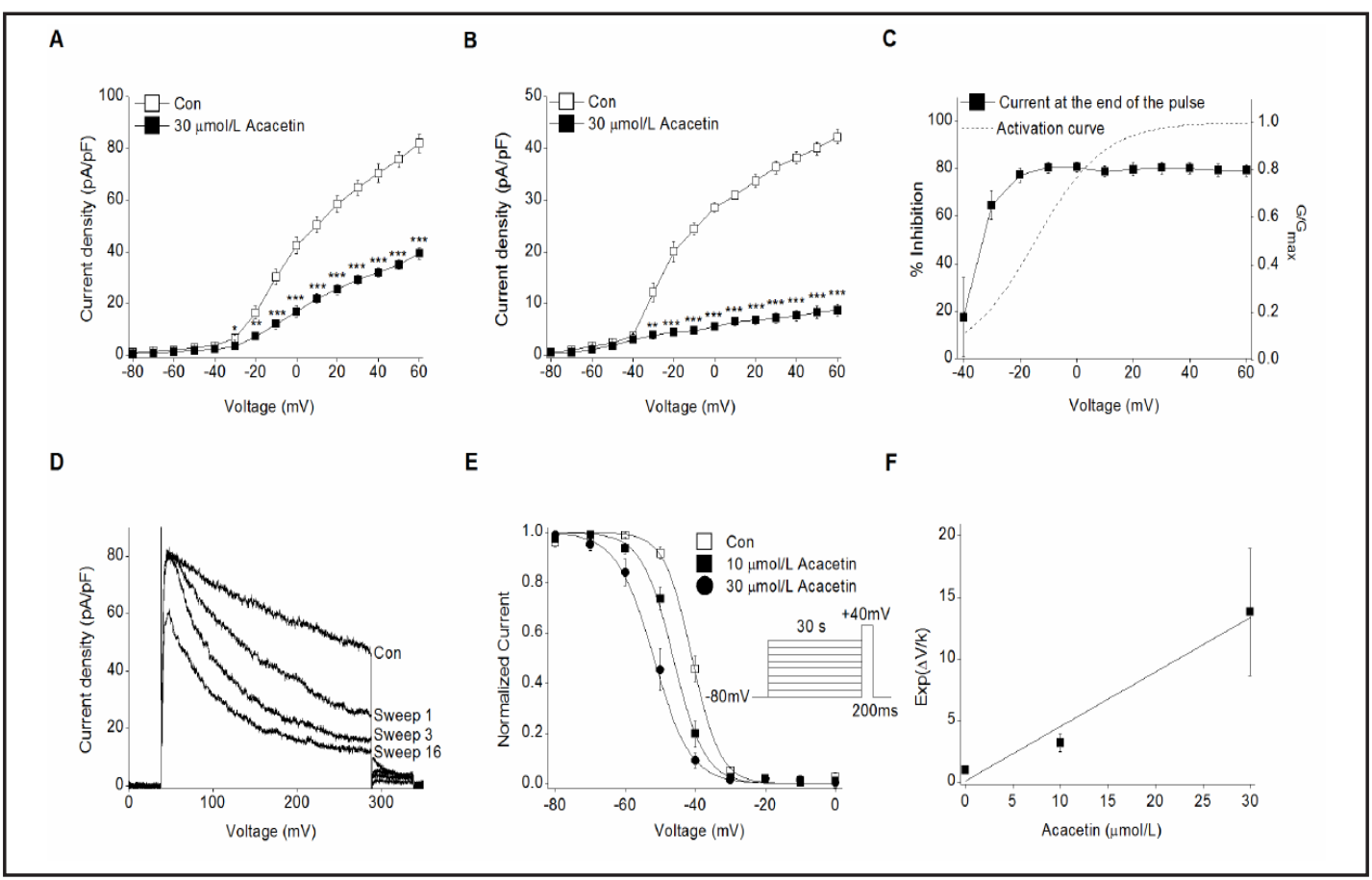

Fig. 3. Blocking kinetics of Acacetin on Kv1.3 channels in Jurkat cells. A. The average current density-voltage relationship for the peak Kv1.3 currents in the control (open square) and in the presence (filled square) of $30 \mu \mathrm{mol} / \mathrm{L}$ Acacetin. Currents were elicited using the same protocol as in Fig. $2 \mathrm{~A}$. B. The average current density-voltage relationship for the Kv1.3 currents at the end of the pulse in the absence (open square) and presence (filled square) of $30 \mu \mathrm{mol} / \mathrm{L}$ Acacetin. C. The inhibition \% of the Kv1.3 currents at the end of the pulse (filled square) was plotted with the test voltages. The dashed line represents the activation curve of Kv1.3 currents under control conditions. D. Superimposed current density traces recorded in the control and after $10 \mu \mathrm{mol} / \mathrm{L}$ Acacetin application. Acacetin was applied to the bath in the pulse-free condition for $8 \mathrm{~min}$, then consecutive depolarization pulses were applied every $10 \mathrm{~s}$. E. The steady-state inactivation curves in the absence and presence of 10 and $30 \mu \mathrm{mol} / \mathrm{L}$ Acacetin. The data were acquired from the normalized currents at $+40 \mathrm{mV}$, which followed a $30 \mathrm{~s}$ pre-pulse of potentials between $-80 \mathrm{mV}$ and $0 \mathrm{mV}$, and fitted with the Boltzman equation. In the control condition, the $V_{1 / 2}$ value was $-40.91 \pm 0.96$ and $\kappa$ was $3.98 \pm 0.42 \mathrm{mV}$. After 10 and $30 \mu \mathrm{mol} / \mathrm{L}$ Acacetin application, the $V_{1 / 2}$ value changed to $-46.32 \pm 0.99$ and $-51.94 \pm 1.08$ and the $\kappa$ value changed to $4.53 \pm 0.33$ and $5.28 \pm 0.36$, respectively. We first recorded the control current after at least $10 \mathrm{~min}$ break-in, and then recorded the currents after 10 and $30 \mu \mathrm{mol} / \mathrm{L}$ Acacetin treatment on the same cell. F. Plot of $\operatorname{Exp}(\Delta V / \kappa)$ against the Acacetin concentration. Potential corresponding to the half-inactivation voltage $\mathrm{V}_{1 / 2}$ and the slope factor $\kappa$ were obtained from the curves in Fig. $3 E$.

$\mathrm{K}_{\mathrm{Ca}}$ channel in PBTC $[6,25]$. Therefore, we checked the blocking effect of Acacetin on $\mathrm{K}_{\mathrm{Ca}}$ currents in both of these two types of human $\mathrm{T}$ cells. $\mathrm{K}_{\mathrm{Ca}}$ channel currents were elicited by ramp pulse, as described previously [14]. The representative current traces in Jurkat T cells and PBTC are shown in Fig. $4 A$ and $4 C$, respectively. To avoid mixture of the outward Kv channel currents, we measured the slope conductance between -120 and $-40 \mathrm{mV}$ by fitting the curve with a linear equation. Acacetin at $30 \mu \mathrm{mol} / \mathrm{L}$ had no apparent effects on the slope factor for $\mathrm{K}_{\mathrm{Ca}}$ in both Jurkat cells and human PBTC (Fig. 4B and 4D). The slope conductance for Jurkat cells was $0.70 \pm 0.04 \mathrm{nS}$ in control condition, and $0.69 \pm 0.05 \mathrm{nS}$ after Acacetin application $(n=5, P>0.05)$. Likewise, the slope conductance for PBTC was $0.92 \pm 0.11 \mathrm{nS}$ in control condition, and $0.94 \pm 0.13 \mathrm{nS}$ after Acacetin application $(\mathrm{n}=5, \mathrm{P}>0.05)$. In Fig. $4 E$ and $4 F$, to increase the slope conductance of $\mathrm{K}_{\mathrm{Ca}}$ current, we recorded the current in a $\mathrm{K}^{+}$ Ringer solution (All NaCl was replaced by $\mathrm{KCl}$ ), and found no block effect by Acacetin $(1.25$ $\pm 0.04 \mathrm{nS}$ vs. $1.24 \pm 0.05 \mathrm{nS}, \mathrm{n}=5, \mathrm{P}>0.05$ ), similarly. In contrast, application of $200 \mathrm{pmol} / \mathrm{L}$ Scyllatoxin, a selective $\mathrm{K}_{\mathrm{Ca}} 2.2$ blocker, robustly decreased the $\mathrm{K}_{\mathrm{Ca}}$ slope conductance (Fig. $4 E$ 
Fig. 4. Effect of Acacetin on $\mathrm{K}_{\mathrm{Ca}}$ channel currents in human $\mathrm{T}$ cells. $\mathrm{K}_{\mathrm{Ca}}$ currents were elicited by a $200 \mathrm{~ms}$ voltage-ramp ranging from -120 to $+40 \mathrm{mV}$ with the holding potential at $-40 \mathrm{mV}$. The slope conductance of $\mathrm{K}_{\mathrm{Ca}}$ currents were obtained using a linear fit between $-120 \mathrm{mV}$ and $-40 \mathrm{mV}$. A. Representative superimposed current-voltage relationships traces recorded in the absence and presence of $30 \mu \mathrm{mol} / \mathrm{L}$ Acacetin in Jurkat cells. B. Summarized data from 6 Jurkat cell experiments. C. Representative $\mathrm{K}_{\mathrm{Ca}}$ current-voltage traces acquired from the PBTCs. D. Summarized data from 5 PBTC experiments. E. Representative superimposed current-voltage relationships traces from Jurkat cells recorded in $\mathrm{K}^{+}$Ringer solution in the absence and presence of $30 \mu \mathrm{mol} / \mathrm{L}$ Acacetin. Inset shows representative superimposed currentvoltage relationships traces from Jurkat cells

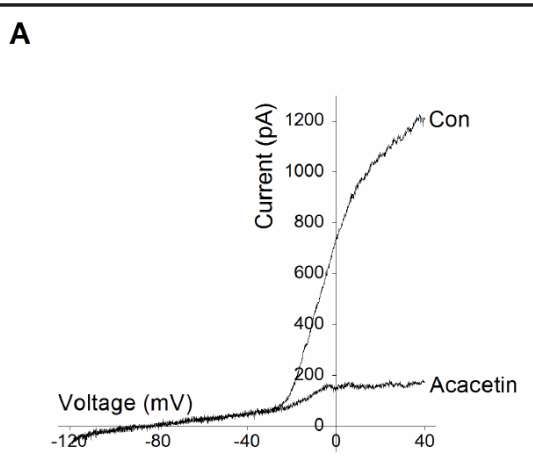
B

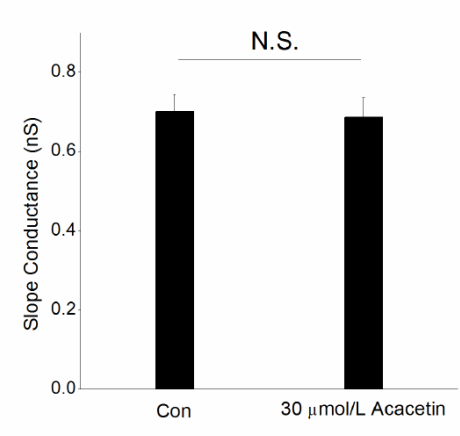

C

D
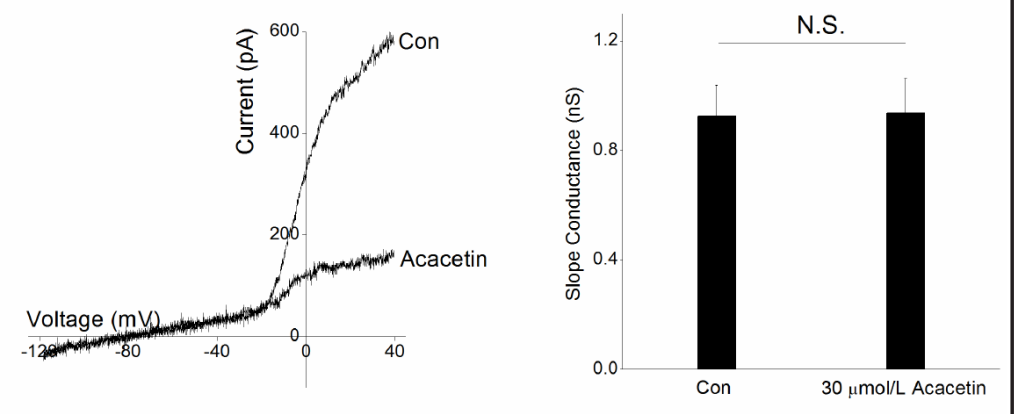

E

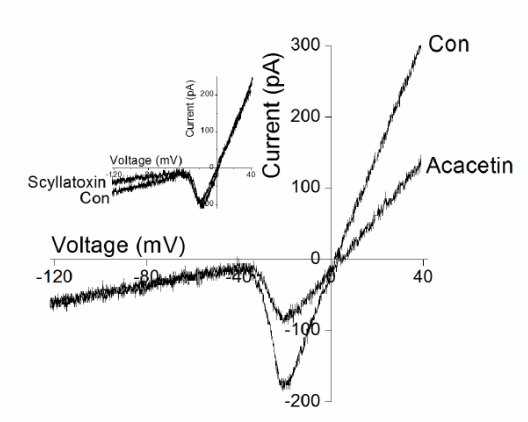

$\mathbf{F}$

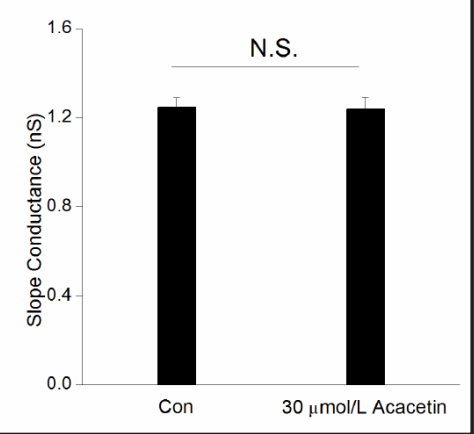
recorded in $\mathrm{K}^{+}$Ringer solution in the absence and presence of $200 \mathrm{pmol} / \mathrm{L}$ Scyllatoxin, a selective $\mathrm{K}_{\mathrm{Ca}} 2.2$ blocker. F. Summarized data from 5 Jurkat experiments. N.S. represented no statistical significance. Data are expressed as the mean \pm SEM.

inset). Therefore, our results suggest that Acacetin has no effect on $\mathrm{K}_{\mathrm{Ca}}$ in human $\mathrm{T}$ cells. Notably, Acacetin at $30 \mu \mathrm{mol} / \mathrm{L}$ blocks most of the current through Kv1.3 channels in Ringer solution (Fig. 4A) but only $50 \%$ in $\mathrm{K}^{+}$Ringer solution (Fig. 4E), which suggests that high extracellular $\mathrm{K}^{+}$might attenuate the block effect of Acacetin on Kv1.3 channels in Jurkat cells. In our previous report [26], high extracellular $\mathrm{K}^{+}$also resulted in a reduced inhibitory effect of Ketanserin on Kv1.3 channels expressed in xenopus oocytes.

\section{Effect of Acacetin on Kv1.3 channel mRNA and protein expression}

In addition to acute inhibition of functional Kv1.3 channels, Kv1.3 blockers have been shown to produce anti-inflammatory and immunomodulatory effects through chronic reduction of the channel expression [11, 12, 14, 27]. Before analysis, we confirmed that treatment with 10, 30 or $100 \mu \mathrm{mol} / \mathrm{L}$ Acacetin for up to $24 \mathrm{~h}$ did not result in any cytotoxicity in Jurkat cells, as assessed using both a CCK-8 kit and trypan blue dye (Fig. $5 \mathrm{~A}$ and Fig. $5 B$ ). To test the effect of Acacetin on Kv1.3 channel expression, we exposed Jurkat cells to 
Fig. 5. Effect of Acacetin on the expression of Kv1.3 channels in Jurkat cells. A. $2 \times 10^{5} /$ well Jurkat cells were seeded into 96-well plate and incubated with 10,30 , or 100 $\mu \mathrm{mol} / \mathrm{L}$ Acacetin for 4-24 h. The cell viability at the indicated time points was estimated using a CCK-8 kit. B. Jurkat cells were incubated with Acacetin $(10,30$, or 100 $\mu \mathrm{mol} / \mathrm{L}$ ) for 24 $\mathrm{h}$, then cell viability was de-

A

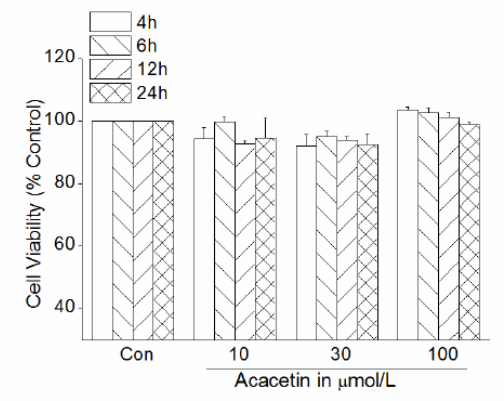

C

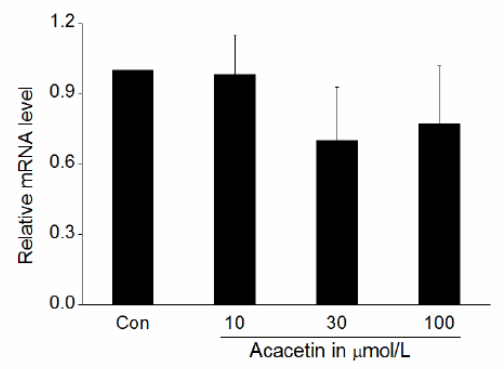

B

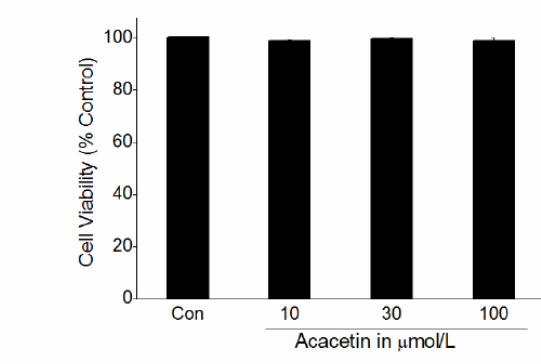

D

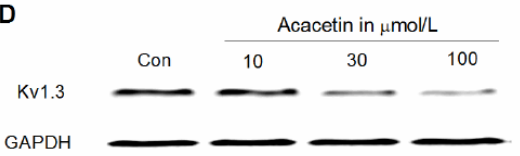

$\mathrm{E}$

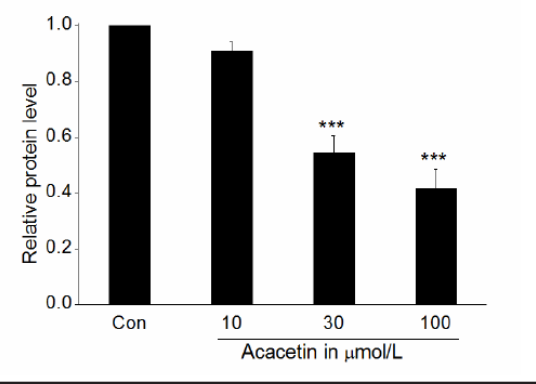

termined using the Typan blue dye exclusion method. C. The relative Kv1.3 mRNA expression level in the absence and presense of 10, 30, or $100 \mu \mathrm{mol} / \mathrm{L}$ Acacetin incubation for $24 \mathrm{~h}$. D. Representative Western blot analysis of Kv1.3 channel protein expression under control conditions and after $24 \mathrm{~h}$ incubation with 10, 30, or $100 \mu \mathrm{mol} / \mathrm{L}$ Acacetin. E. The data from at least 3 replicates that were normalized to the protein expression of GAPDH are shown $\left({ }^{* *} \mathrm{P}<0.001\right.$ vs. control). The data are expressed as the mean $\pm \mathrm{SEM}$.

increasing drug concentrations ( $24 \mathrm{~h}$ ) and measured the effects on Kv1.3 mRNA and protein processing using real-time PCR and Western blot analysis. Treatment with Acacetin had no effect on mRNA expression (Fig. $5 C$ ), but produced a concentration-dependent decrease in the amount of Kv1.3 protein (Fig. $5 D$ and $5 E$ ). On average, 10, 30 and $100 \mu \mathrm{mol} / \mathrm{L}$ Acacetin decreased Kv1.3 protein expression by 9\%, 46\% and 59\%, respectively (Fig. $5 E$ ).

\section{Acacetin decreases the Ca2+ influx to Ca2+-depleted Jurkat cells}

Many studies have shown that Kv1.3 channels control $\mathrm{Ca}^{2+}$ homeostasis by maintaining the negative membrane potential in T cells and inhibition of Kv1.3 channels significantly depolarizes the membrane potential, reducing the $\mathrm{Ca}^{2+}$ influx $[11,12,14]$. Our current-clamp recordings have shown that the RMP depolarized from $-41.57 \pm 0.90 \mathrm{mV}$ in the control to $-22.35 \pm 1.66 \mathrm{mV}(\mathrm{n}=6, \mathrm{P}<0.001)$ after $7-8 \mathrm{~min}$ application of $30 \mu \mathrm{mol} / \mathrm{L}$ Acacetin. To further confirm that Acacetin inhibits $\mathrm{Ca}^{2+}$ influx, we measured the intracellular $\mathrm{Ca}^{2+}$ concentration using a similar protocol as in previous studies [11]. Treatment of the cells with Acacetin (10, 30 or $100 \mu \mathrm{mol} / \mathrm{L}$ ) for $30 \mathrm{~min}$ had no effects on TG-induced intracellular $\mathrm{Ca}^{2+}$, except at 100 $\mu \mathrm{mol} / \mathrm{L}$ (Fig. $6 A$ and $6 B$ ) but significantly reduced the sustained $\mathrm{Ca}^{2+}$ influx in a concentrationdependent manner (Fig. $6 \mathrm{~A}$ and $6 \mathrm{C}$ ). On average, 10, 30 and $100 \mu \mathrm{mol} / \mathrm{L}$ Acacetin reduce $\mathrm{Ca}^{2+}$ influx by $13.54 \%, 38.27 \%, 52.55 \%$, respectively.

\section{Acacetin modulates the transcription factors NFAT1 and NF- $\kappa B$ p65/p50}

The activation of $\mathrm{T}$ cells is mediated by $\mathrm{Ca}^{2+}$ influx and $\mathrm{Ca}^{2+}$-activated transcription factors such as NFAT and NF- $\mathrm{BB}$ in human T cells $[9,28]$. We thus determined whether 


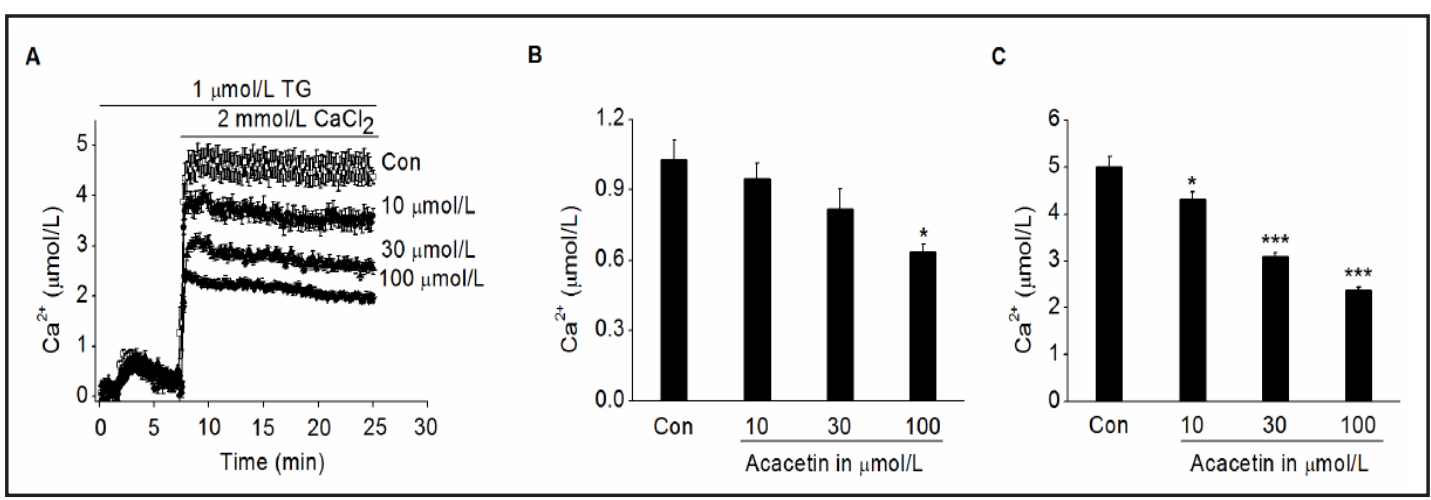

Fig. 6. Blocking effect of Acacetin on $\mathrm{Ca}^{2+}$ influx in Jurkat cells. Jurkat cells were loaded with fluo-4, washed and re-suspended in $\mathrm{Ca}^{2+}$-free Ringer solution. Then, 0, 10, 30 or $100 \mu \mathrm{mol} / \mathrm{L}$ Acacetin was added into the extracellular solution. After $30 \mathrm{~min}$ incubation, intracellular $\mathrm{Ca}^{2+}$ release was elicited by $1 \mu \mathrm{mol} / \mathrm{L}$ TG application. After approximately $7 \mathrm{~min}, 2 \mathrm{mmol} / \mathrm{L} \mathrm{CaCl}_{2}$ was applied to induce a rapid and sustained $\mathrm{Ca}^{2+}$ influx. A. An average $\mathrm{Ca}^{2+}$ concentration time course is shown for the control as well as for cells treated with 10,30 , or $100 \mu \mathrm{mol} / \mathrm{L}$ Acacetin. B. The summarized data of the peak $\mathrm{Ca}^{2+}$ release response induced by TG. C. The summarized data of the peak $\mathrm{Ca}^{2+}$ influx response with the application of $2 \mathrm{mM} \mathrm{CaCl}_{2}{ }^{*} \mathrm{P}<0.05$ and ${ }^{* * *} \mathrm{P}<0.001$ vs. control. The data are expressed as the mean \pm SEM and acquired from at least 5 replicate experiments. The experiments were carried out at room temperature.

Fig. 7. Effect of Acacetin on NFAT1 and NFкB p65/p50 activity in Jurkat cells. Jurkat cells were preincubated with $0,10,30$, or 100 $\mu \mathrm{mol} / \mathrm{L}$ Acacetin for $30 \mathrm{~min}$, then the cells were stimulated with PHA+PMA as in Fig. $7 A$. The cells received equal volumes of DMSO as a control. A. Representative Western blot analysis of

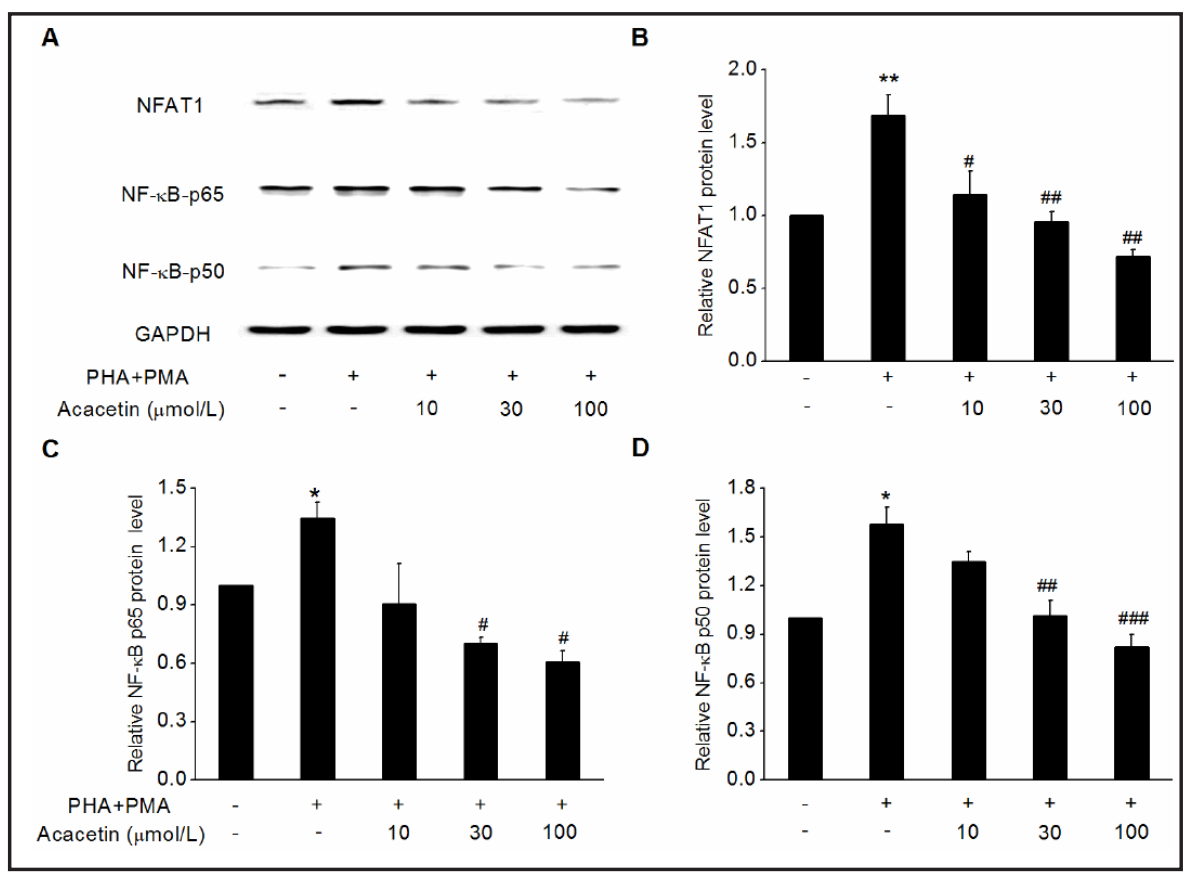
NFAT1 and phospho-NF- $\mathrm{B}$ p65/p50. The statistical analysis of the relative protein expression is shown in B (NFAT1), C (p65), and D (p50). The data are expressed as the mean \pm SEM. $* \mathrm{P}<0.05, * * \mathrm{P}<0.01$ vs. control, \# $\mathrm{P}<0.05$, \#\# $\mathrm{P}<0.01$ and \#\#\# $\mathrm{P}<0.001$ vs. a stimulated group without Acacetin treatment. The experiments were carried out at room temperature.

Acacetin modulated the activity of these transcription factors. As shown in Fig. 7, the expression of NFAT1 and phospho-NF- $\kappa B$ (p65 and p50) in the nucleus was increased upon stimulation with PHA+PMA (P <0.05). However, treatment with Acacetin $(10,30$ and 100 $\mu \mathrm{mol} / \mathrm{L}$ ) significantly suppressed the level of both transcription factors in a concentrationdependent manner. 
A

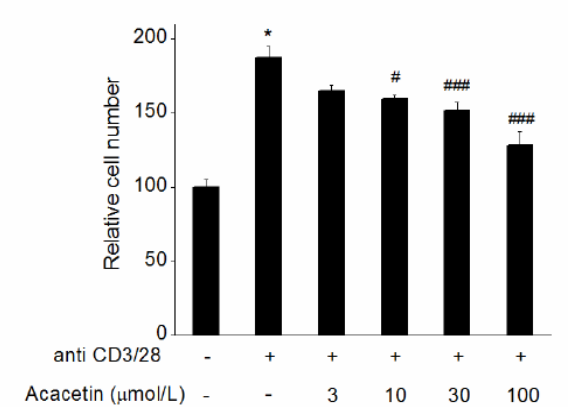

C

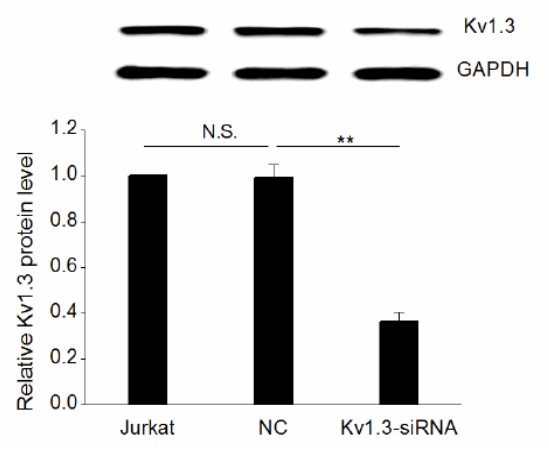

B

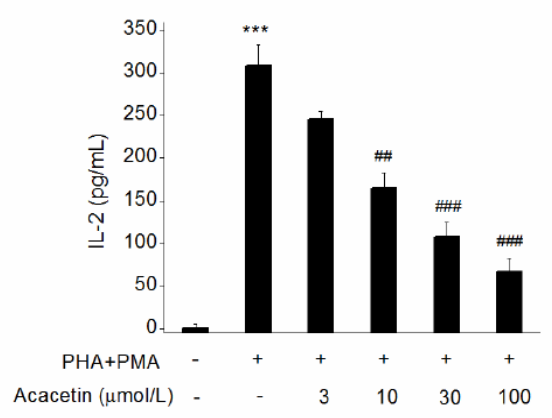

D

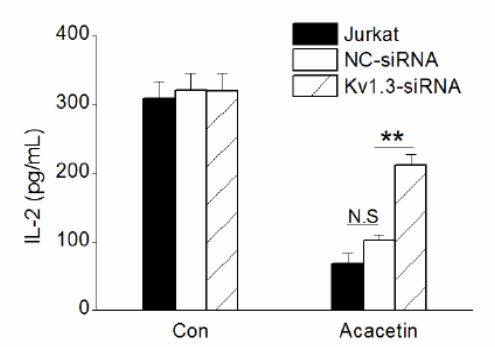

Fig. 8. Effects of Acacetin on T cell proliferation and IL-2 secretion in human T cells. A. PBTC were seeded into a 96-well plate and pre-treated with various concentrations $(0,3,10,30$, and $100 \mu \mathrm{mol} / \mathrm{L})$ of Acacetin. After $30 \mathrm{~min}$, anti-CD3/CD28 antibodies were applied to induce T cell proliferation for 3 days. The relative cell number was determined using a CCK-8 kit. B. Jurkat cells were pre-incubated with 0, 3, 10, 30, or 100 $\mu \mathrm{mol} / \mathrm{L}$ Acacetin for $30 \mathrm{~min}$, then stimulated with PHA (5 $\mathrm{\mu g} / \mathrm{mL})$ and PMA ( $80 \mathrm{nmol} / \mathrm{L})$ for $24 \mathrm{~h}$. The supernatants were collected for IL-2 measurement. Cells receiving equal volumes of DMSO were used as a control. The data are expressed as the mean \pm SEM. ${ }^{*} \mathrm{P}<0.05$, ${ }^{* * *} \mathrm{P}<0.001$ vs. control, \# $\mathrm{P}<0.05$, \#\# $\mathrm{P}<0.01$ and \#\#\# $\mathrm{P}<0.001$ vs. a stimulated group without Acacetin treatment. C. Jurkat cells and cells transfected with NC- or Kv1.3-siRNA were measured for their Kv1.3 protein expression level using a Western blot. D. Jurkat cells and cells transfected with NC- or Kv1.3-siRNA were pretreated with 0 or $100 \mu \mathrm{mol} / \mathrm{L}$ Acacetin for 30min, then stimulated with PHA and PMA for $24 \mathrm{~h}$. The supernatants were collected for IL-2 measurement. ${ }^{* *} \mathrm{P}<0.01$ vs a NC-siRNA group. N.S. represented no statistical significance. Data are expressed as the mean \pm SEM.

\section{T cell proliferation and IL-2 secretion are inhibited by Acacetin}

To determine whether Kv1.3 channel and $\mathrm{Ca}^{2+}$ signaling pathway inhibition by Acacetin could result in functional immunosuppression, we evaluated T cell proliferation and IL-2 secretion. Cell proliferation was assessed in human anti-CD3/CD28-stimulated T cells using a CCK-8 kit, and IL-2 production in the cell culture supernatants of PMA/PHA-stimulated Jurkat cells was measured using ELISA. Treatment of the cells with Acacetin $(3,10,30$ or $100 \mu \mathrm{mol} / \mathrm{L})$ resulted in a concentration-dependent reduction in the number of $\mathrm{T}$ cells (Fig. 8A) and IL-2 secretion (Fig. 8B). To prove that Kv1.3 is involved in the inhibitory effect of Acacetin on IL-2 secretion, we knocked down Kv1.3 expression in Jurkat cells by using specific Kv1.3 siRNA. We found that the transfection of kv1.3-siRNA resulted in $64.68 \%$ knockdown of the Kv1.3 protein and that NC-siRNA transfection caused no apparent change in the Kv1.3 channels ( $\mathrm{P}=0.873$, Fig. $8 C$ ). Importantly, we demonstrated that knockdown of the Kv1.3 channels resulted in a reduced inhibitory effect of $100 \mu \mathrm{mol} / \mathrm{L}$ Acacetin on IL-2 secretion $(34.07 \pm 5.23 \%$ vs. NC-siRNA $68.35 \pm 4.05 \%$, P<0.01). In contrast, NC-siRNA had no effect on the Acacetin induced-inhibitory effects $(68.35 \pm 4.05 \%$ vs. Jurkat cell $78.14 \pm$ $4.83 \%, \mathrm{P}=0.196)$. Taken together, these results suggested that Acacetin most likely exerts its anti-inflammatory effect at least partly through Kv1.3 channels. 


\section{Discussion}

This is the first study to investigate the effect of Acacetin on Kv1.3 channels in human $\mathrm{T}$ cells. Our results demonstrated that Acacetin blocked the Kv1.3 channels in a voltage- and concentration-dependent fashion without an apparent effect on $\mathrm{K}_{\mathrm{Ca}}$ channel currents. Up to $24 \mathrm{~h}$ incubation with Acacetin had no significant effect on cell viability or Kv1.3 mRNA expression level but apparently inhibited Kv1.3 protein expression, which may contribute to its long-term inhibitory effect. Acacetin also inhibited the $\mathrm{Ca}^{2+}$ influx and $\mathrm{Ca}^{2+}$-activated transcription factors NFAT1 and NF- $\kappa B$ p65/50. Similar to many other Kv1.3 blockers [11, 12], Acacetin inhibited T cell proliferation as well as IL-2 secretion. Furthermore, siRNA knockdown of Kv1.3 channels reduced the inhibitory effect of Acacetin on IL-2 secretion. Therefore, our results suggest that Acacetin mediates its immunomodulatory and antiinflammatory effects by blocking Kv1.3 channels.

The Acacetin induced time-dependent blockade of Kv1.3 channels could be due to several mechanisms. As shown in Figs. 1, 2 and 3, there was little inhibition of Kv1.3 at the onset of depolarization, indicating that Acacetin does not preferentially bind to the closed state of the channel. However, upon depolarization, Acacetin accelerated the time course of decay of the Kv1.3 currents in a concentration-dependent manner, correspondingly causing a greater reduction in the currents at the end of the pulse than the peak currents. These results suggest that Acacetin blocks the Kv1.3 channel open state and/or binds the inactivated state of the channel. As shown in Fig. 3, Acacetin blocked the Kv1.3 channel in a voltage-dependent manner, and this inhibitory effect increased upon voltage range channel activation. Furthermore, Acacetin did not exert any obvious effect until the channel was first opened by a depolarization pulse. The voltage dependence and the development kinetics of the block strongly support a mechanism whereby Acacetin blocks the open state, which is the same mechanism previously observed for the Kv1.5 channel [29]. However, unlike other open channel blockers of the Kv1.3 channel [23, 30], Acacetin failed to cause a crossover phenomenon of tail current traces, which may indicate that Acacetin is not a pure Kv1.3 open channel blocker. Indeed, Acacetin might also inhibit the inactivated-state channel, which is reflected in the negatively shift of the steady-state inactivation curves in a concentrationdependent manner. Affinity for both the open and the inactivated-state has been previously described for other Kv1.3 channel blockers, including FK-506, verapamil, diphenyl phosphine oxide- 1 and $18 \beta$-glycyrrhetinic acid [11, 14, 24, 31].

Blockade of the Kv1.3 channels inhibits T cell activation by depolarizing the membrane potential, thereby attenuating the $\mathrm{Ca}^{2+}$ signaling and subsequent cell proliferation $[6,9,14$, $32,33]$. These characteristic features are clearly demonstrated for Acacetin in the present study. Acacetin in concentrations that block the Kv1.3 channel depolarized the membrane potential, blunted $\mathrm{Ca}^{2+}$ influx, down-regulated the $\mathrm{Ca}^{2+}$-activated transcription factors NFAT1 and NF- $\kappa \mathrm{B}$ p 65/p50, and inhibited T cell proliferation and production of IL-2. Furthermore, $24 \mathrm{~h}$ incubation with Acacetin caused inhibition of Kv1.3 protein expression, which may strengthen the long-term effect of Acacetin on Kv1.3 channels. However, $24 \mathrm{~h}$ incubation with Acacetin had no effect on the mRNA expression of Kv1.3, and so we may conclude that Acacetin inhibited Kv1.3 protein expression by targeting the post-transcriptional mechanism. In addition, our electrophysiological data shows that acute application of 30 $\mu \mathrm{mol} / \mathrm{L}$ Acacetin blocked the Kv1.3 channel, but had little effect on the $\mathrm{K}_{\mathrm{Ca}}$ channels, which should make Acacetin ideal for specific immune suppression, i.e., inhibiting the autoimmune reaction without compromising the physiological immune response. The latter is based on the up-regulation of the $\mathrm{K}_{\mathrm{Ca}}$ channel expression in activated naïve and central memory $\mathrm{T}$ cells. However, whether Acacetin has a direct blocking effect on CRAC channels, through which $\mathrm{Ca}^{2+}$ entry mediates $\mathrm{T}$ cell activation, requires further investigation. Acacetin may also directly target the inflammation-related transcription factors [34] or the inflammatory intermediates iNOS and COX-2 [2]. Consistent with these findings, in animal models, Acacetin can ameliorate autoimmune delayed-type hypersensitivity and have no obvious side effects [3]. This confers a therapeutic potential for Acacetin against human T cell-mediated inflammatory diseases, such as multiple sclerosis, rheumatoid arthritis, and psoriasis. 
In summary, our data provide the first evidence that the direct inhibition of the Kv1.3 channel is likely involved in the mechanisms of Acacetin-induced anti-inflammatory and immunomodulatory effects.

\section{Disclosure Statement}

The authors declare that they have no competing interests.

\section{Acknowledgements}

This work was supported by the National Nature Science Foundation of China (No. 81170164) to Dr. Du, Open Foundation of Hubei Key Laboratory of Biological Targeted Therapy (No. 2013-81) to Dr. Zhao and the National Basic Research Program of China (973 Program: 2013CB531103) to Dr. Cheng. We thank Mr. Guo He-Ping of his contribution for the blood sample collection.

\section{References}

1 Ha SK, Moon E, Lee P, Ryu JH, Oh MS, Kim SY: Acacetin attenuates neuroinflammation via regulation the response to LPS stimuli in vitro and in vivo. Neurochem Res 2012;37:1560-1567.

2 Pan MH, Lai CS, Wang YJ, Ho CT: Acacetin suppressed LPS-induced up-expression of iNOS and COX-2 in murine macrophages and TPA-induced tumor promotion in mice. Biochem Pharmacol 2006;72:12931303.

-3 Yin Y, Gong FY, Wu XX, Sun Y, Li YH, Chen T, Xu Q: Anti-inflammatory and immunosuppressive effect of flavones isolated from Artemisia vestita. J Ethnopharmacol 2008;120:1-6.

- 4 Li GR, Wang HB, Qin GW, Jin MW, Tang Q Sun HY, Du XL, Deng XL, Zhang XH, Chen JB, Chen L, Xu XH, Cheng LC, Chiu SW, Tse HF, Vanhoutte PM, Lau CP: Acacetin, a natural flavone, selectively inhibits human atrial repolarization potassium currents and prevents atrial fibrillation in dogs. Circulation 2008;117:24492457.

-5 Fujii M, Hayashi K, Ohya S, Yamamura H, Imaizumi Y: New screening system for selective blockers of Voltage-Gated k channels using recombinant cell lines dying upon single action potential. J Pharmacol Sci 2013:123:147-58.

6 Cahalan MD, Chandy KG: The functional network of ion channels in Tymphocytes. Immunol Rev 2009;231:59-87.

7 Vicente R, Escalada A, Villalonga N, Texido L, Roura-Ferrer M, Martin-Satue M, Lopez-Iglesias C, Soler C, Solsona C, Tamkun MM, Felipe A: Association of Kv1.5 and Kv1.3 contributes to the major voltagedependent $\mathrm{K}^{+}$channel in macrophages. J Biol Chem 2006;281:37675-37685.

8 Mullen KM, Rozycka M, Rus H, Hu L, Cudrici C, Zafranskaia E, Pennington MW, Johns DC, Judge SI, Calabresi PA: Potassium channels Kv1.3 and Kv1.5 are expressed on blood-derived dendritic cells in the central nervous system. Ann Neurol 2006;60:118-127.

-9 Feske S: Calcium signalling in lymphocyte activation and disease. Nat Rev Immunol 2007;7:690-702.

-10 Leonard RJ, Garcia ML, Slaughter RS, Reuben JP: Selective blockers of voltage-gated $\mathrm{K}^{+}$channels depolarize human T lymphocytes: Mechanism of the antiproliferative effect of charybdotoxin. Proc Natl Acad Sci USA 1992;89:10094-10098.

11 Fu XX, Du LL, Zhao N, Dong Q Liao YH, Du YM: 18Beta-Glycyrrhetinic acid potently inhibits Kv1.3 potassium channels and T cell activation in human Jurkat T cells. J Ethnopharmacol 2013:148:647-54.

-12 Li Z, Liu WH, Han S, Peng BW, Yin J, Wu YL, He XH, Li WX: Selective inhibition of CCR7- effector memory T cell activation by a novel peptide targeting Kv1.3 in a rat experimental autoimmune encephalomyelitis model. J Biol Chem 2012:287:29479-94.

13 Price M, Lee SC, Deutsch C: Charybdotoxin inhibits proliferation and interleukin 2 production in human peripheral blood lymphocytes. Proc Natl Acad Sci USA 1989;86:10171-10175.

14 Zhao N, Dong Q Du LL, Fu XX, Du YM, Liao YH: Potent suppression of kv1.3 potassium channel and IL-2 secretion by diphenyl phosphine oxide-1 in human t cells. PLoS One 2013;8:e64629.

15 Azam P, Sankaranarayanan A, Homerick D, Griffey S, Wulff H: Targeting effector memory T cells with the small molecule Kv1.3 blocker PAP-1 suppresses allergic contact dermatitis. J Invest Dermatol 2007;127:1419-1429. 
-16 Beeton C, Wulff H, Standifer NE, Azam P, Mullen KM, Pennington MW, Kolski-Andreaco A, Wei E, Grino A, Counts DR, Wang PH, LeeHealey CJ, S AB, Sankaranarayanan A, Homerick D, Roeck WW, Tehranzadeh J, Stanhope KL, Zimin P, Havel PJ, Griffey S, Knaus HG, Nepom GT, Gutman GA, Calabresi PA, Chandy KG: Kv1.3 channels are a therapeutic target for T cell-mediated autoimmune diseases. Proc Natl Acad Sci U S A 2006;103:17414-17419.

17 Wulff H, Calabresi PA, Allie R, Yun S, Pennington M, Beeton C, Chandy KG: The voltage-gated Kv1.3 K channel in effector memory T cells as new target for MS. J Clin Invest 2003;111:1703-1713.

-18 Beeton C, Wulff H, Barbaria J, Clot-Faybesse O, Pennington M, Bernard D, Cahalan MD, Chandy KG, Beraud E: Selective blockade of $\mathrm{T}$ lymphocyte $\mathrm{K}^{+}$channels ameliorates experimental autoimmune encephalomyelitis, a model for multiple sclerosis. Proc Natl Acad Sci U S A 2001;98:13942-13947.

$\checkmark 19$ Chandy KG, Wulff H, Beeton C, Pennington M, Gutman GA, Cahalan MD: $\mathrm{K}^{+}$channels as targets for specific immunomodulation. Trends Pharmacol Sci 2004;25:280-289.

20 Maltsev VA: Oscillating and triggering properties of T cell membrane potential. Immunol Lett 1990;26:277282.

21 Zegarra-Moran O, Rasola A, Rugolo M, Porcelli AM, Rossi B, Galietta LJ: HIV-1 nef expression inhibits the activity of a $\mathrm{Ca}^{2+}$-dependent $\mathrm{K}^{+}$channel involved in the control of the resting potential in CEM lymphocytes. J Immunol 1999;162:5359-5366.

-22 Zitt C, Strauss B, Schwarz EC, Spaeth N, Rast G, Hatzelmann A, Hoth M: Potent inhibition of Ca ${ }^{2+}$ releaseactivated $\mathrm{Ca}^{2+}$ channels and T-lymphocyte activation by the pyrazole derivative BTP2. J Biol Chem 2004;279:12427-12437.

23 Ahn HS, Kim SE, Jang HJ, Kim MJ, Rhie DJ, Yoon SH, Jo YH, Kim MS, Sung KW, Kim SY, Hahn SJ: Open channel block of Kv1.3 by rosiglitazone and troglitazone: Kv1.3 as the pharmacological target for rosiglitazone. Naunyn Schmiedebergs Arch Pharmacol 2007;374:305-309.

24 Ahn HS, Kim SE, Choi BH, Choi JS, Kim MJ, Rhie DJ, Yoon SH, Jo YH, Kim MS, Sung KW, Kwon OJ, Hahn SJ: Calcineurin-independent inhibition of $\mathrm{K}_{\mathrm{v}} 1.3$ by FK-506 (tacrolimus): A novel pharmacological property. Am J Physiol Cell Physiol 2007;292:C1714-C1722.

25 Grissmer S, Lewis RS, Cahalan MD: $\mathrm{Ca}^{2+}$-activated $\mathrm{K}^{+}$channels in human leukemic T cells. J Gen Physiol 1992;99:63-84.

26 Liang ZT, Wang XP, Zeng QT, Liao YH, Zou AR, Li L, and Tu D N: High extracellular potassium ion concentration attenuates the blockade action of ketanserin on Kv1.3 channels expressed in xenopus oocytes. Chin Med J (Engl), 2008;121:2584-2591.

27 Villalonga N, David M, Bielanska J, Gonzalez T, Parra D, Soler C, Comes N, Valenzuela C, Felipe A: Immunomodulatory effects of diclofenac in leukocytes through the targeting of Kv1.3 voltage-dependent potassium channels. Biochem Pharmacol 2010;80:858-866.

28 Randriamampita C, Trautmann A: $\mathrm{Ca}^{2+}$ signals and T lymphocytes; "New mechanisms and functions in $\mathrm{Ca}^{2+}$ signalling". Biol Cell 2004;96:69-78.

29 Wu HJ, Wu W, Sun HY, Qin GW, Wang HB, Wang P, Yalamanchili HK, Wang J, Tse HF, Lau CP, Vanhoutte PM, Li GR: Acacetin causes a frequency- and use-dependent blockade of hKv1.5 channels by binding to the S6 domain. J Mol Cell Cardiol 2011;51:966-973.

-30 Choi JS, Hahn SJ, Rhie DJ, Yoon SH, Jo YH, Kim MS: Mechanism of fluoxetine block of cloned voltageactivated potassium channel Kv1.3. J Pharmacol Exp Ther 1999;291:1-6.

-31 Robe RJ, Grissmer S: Block of the lymphocyte $\mathrm{K}^{+}$channel mKv1.3 by the phenylalkylamine verapamil: Kinetic aspects of block and disruption of accumulation of block by a single point mutation. Br J Pharmacol 2000;131:1275-1284.

- 32 Vennekamp J, Wulff H, Beeton C, Calabresi PA, Grissmer S, Hansel W, Chandy KG: Kv1.3-blocking 5-phenylalkoxypsoralens: A new class of immunomodulators. Mol Pharmacol 2004;65:1364-1374.

-33 Hanson DC, Nguyen A, Mather RJ, Rauer H, Koch K, Burgess LE, Rizzi JP, Donovan CB, Bruns MJ, Canniff PC, Cunningham AC, Verdries KA, Mena E, Kath JC, Gutman GA, Cahalan MD, Grissmer S, Chandy KG: UK-78,282, a novel piperidine compound that potently blocks the Kv1.3 voltage-gated potassium channel and inhibits human T cell activation. Br J Pharmacol 1999;126:1707-1716.

- 34 Tanigawa N, Hagiwara M, Tada H, Komatsu T, Sugiura S, Kobayashi K, Kato Y, Ishida N, Nishida K, Ninomiya M, Koketsu M, Matsushita K: Acacetin inhibits expression of E-selectin on endothelial cells through regulation of the MAP kinase signaling pathway and activation of NF-kappaB. Immunopharmacol Immunotoxicol 2013;35:471-477. 